\title{
BEBERAPA ASPEK BIOLOGI IKAN NILEM (Osteochillus vittatus) DI DANAU TALAGA, SULAWESI TENGAH
}

\section{SOME BIOLOGICAL ASPECTS OF BONYLIP BARB, (Osteochillus vittatus) IN LAKE TALAGA, CENTRAL SULAWESI}

\author{
Masayu Rahmia Anwar Putri, Yayuk Sugianti \& Krismono \\ Balai Penelitian Pemulihan dan Konservasi Sumberdaya Ikan, Jatiluhur \\ Teregistrasi I tanggal: 26 Mei 2014; Diterima setelah perbaikan tanggal: 10 Agustus 2015; \\ Disetujui terbit tanggal: 13 Agustus 2015 \\ e-mail: masayurahmia33@gmail.com
}

\begin{abstract}
ABSTRAK
Ikan nilem (Osteochillus vittatus) merupakan ikan introduksi di Danau Talaga, Kabupaten Donggala, Sulawesi Tengah. Studi tentang biologi populasi suatu spesiesakan membantu dalam memahami pengelolaannya. Penelitian ini bertujuan untuk mengetahui beberapa aspek biologi ikan nilem (Osteochillus vittatus)sebagai informasi dasar dalam langkah pengelolaan sumberdaya ikan di Danau Talaga. Penelitian ini dilaksanakan pada bulan Maret, Mei, Juli dan Oktober Tahun 2013. Sampel ikan nilem diperoleh dengan melakukan percobaan penangkapan menggunakan 2 set jaring insang (ukuran mata jaring 1, 11/2, 2, 3 dan 4 inci). Ikan yang didapat, diukur panjang total $(\mathrm{cm})$ dan beratnya $(\mathrm{g})$. Pengamatan isi perut dan gonad dilakukan di laboratorium Biologi Ikan, Balai Penelitian Pemulihan dan Konservasi Sumberdaya Ikan.Ikan nilem merupakan ikan yang dominan tertangkap di Danau Talaga dengan kisaran ukuran panjang antara 11-22,7 cm dan ukuran berat antara 15,79-171,43 g, dimana ikan dengan kelompok panjang antara $14-15 \mathrm{~cm}$ mendominasi tangkapan. Pola pertumbuhan ikan nilem bersifat alometrik negatif. Ikan nilem dikategorikan sebagai ikan herbivor dengan makanan utamanya adalah tumbuhan. Ikan nilem yang dominan tertangkap berada pada tingkat kematangan gonad (TKG) IV, dimana ukuran pertama kali matang gonad $\left(\mathrm{L}_{\mathrm{m}}\right)$ baik jantan atau betina lebih kecil dibandingkan $\mathrm{L}_{\mathrm{m}}$ ikan nilem pada beberapa referensi. Hal ini mengindikasikan bahwa ikan nilem di Danau Talaga matang gonad pada ukuran yang lebih kecil. Tipe pemijahan ikan nilem di Danau Talagaadalah total spawner dan dapat memijah sepanjang tahun.
\end{abstract}

KATA KUNCI: Nilem, makanan, pola pertumbuhan, kematangan gonad, tipe pemijahan, fekunditas

\begin{abstract}
Bonylip barb (Osteochillus vittatus) was one of introduction fish species in Sulawesi waters, including Lake Talaga, Donggala,Central Sulawesi. Study on biology populationof species will assist in understanding ofits management. The aim of this research is to know some biological aspects of bonylip barb as basic information in fish resource management of Lake Talaga. The researchwas conducted on March, May, July and October 2013. The fish samples werecaptured by 2 sets experimental gillnet(mesh size 1, 11/2, 2, 3 and 4 inch). These samples then measured its length and weight. The stomach content and gonad was observed at biological laboratory of Research institute for Fisheries Enhancement and Conservation. Bonylip barb is a dominant fish at Lake Talag a with the length range between 11-22.7 cm and weight range between 15.79-171.43 g. The fishes with the length group 14-15 cm were dominatedin fish catch. Bonylip barbwas an herbivore fish with plants as the main food. Thefish with stage IV of gonadsmaturitywere dominated, with the first length of maturity $(\mathrm{Lm})$ inLake Talagawas smaller than other references, either male or female fish.It was indicatedthat in Lake Talaga, bonylip barb fishwas matured in smaller size. Thebonylip barb is a total spawner and the spawning period of it may occurred throughout the year.
\end{abstract}

\section{KEYWORDS: Bonylip barb, food, growth pattern, gona maturity, spawning type, fecundity}

\section{PENDAHULUAN}

Ikan nilem (Osteochillus vittatus) merupakan ikan dari famili Cyprinidae yang tersebar di perairan Sumatera, Jawa dan Kalimantan (Kottelat, 1998). Ikan ini adalah salah satu komoditas budidaya ikan air tawar yang terkonsentrasi di Pulau Jawa, yang umumnya menjadi produk sampingan dari hasil budidaya ikan mas, mujaer, nila atau gurame (Subagja et al., 2007).
Upaya peningkatan populasi dan produksi hasil perikanan melalui kegiatan penebaran beberapa jenis ikan pada berbagai badan air dilakukan oleh beberapa instansi, salah satunya di perairan Sulawesi (Dinas Kelautan dan Perikanan Provinsi Sulawesi Tengah, 2012).Salah satu jenis ikan introduksi di perairan Sulawesi adalahikan nilem yang diketahui populasinya meningkat di Danau Poso, Sulawesi Tengah (Subagja et al., 2013), dan di perairan Danau Talaga, Sulawesi Tengah. 
Danau Talagayang terletak di Kabupaten Donggala, Sulawesi Tengah merupakan salah satu badan air yang menjadi lokasi introduksi ikan. Penyebaran ikan nilem di Danau Talaga terjadi secara tidak sengaja, masuk bersamaan benih ikan yang diintroduksi. Sayangnya peningkatan populasi ikan ini tidak diiringi minat masyarakat sekitar untuk mengkonsumsinya (Adriani, komunikasi pribadi, 2013). Jika tidak dimanfaatkan dikhawatirkan akan terjadi ledakan populasi ikan nilem, sehingga akan mengganggu keseimbangan ekosistem Danau Talaga.

Invasi dari ikan introduksi telah menyebabkan penurunan keanekaragaman jenis ikan asli air tawar di berbagai belahan dunia (Zhu et al., 2014). Studi tentang biologi populasi spesies invasive akan membantu dalam memahami pengelolaannya (Sakai et al., 2001). Penelitian ini bertujuan untuk mengkaji beberapa aspek biologi ikan nilem (Osteochillus vittatus), seperti sebaran ukuran panjang, hubungan panjang berat, kebiasaan makan, tingkat kematangan gonad (TKG), ukuran ikan pertama kali matang gonad (Lm), indeks kematangan gonad (IKG), ukuran diameter telur dan fekunditas ikan nilem sebagai informasi dasar dalam langkah pengelolaan sumberdaya ikan di Danau Talaga, Sulawesi Tengah.

\section{BAHANDANMETODE}

Penelitian ini dilaksanakan pada bulan Maret, Mei, Juli dan Oktober Tahun 2013 di Danau Talaga, Kabupaten Donggala, Sulawesi Tengah. Sampel ikan nilem diperoleh dengan melakukan percobaan penangkapan menggunakan 2 set jaring insang (gillnet) dengan ukuran mata jaring 1, 1⁄1/2, 2, 3 dan 4 inci. Jaring dipasang pada dua stasiun yang mewakili bagian tepi (st. 1) dan bagian tengah Danau Talaga (st. 2) (Gambar 1).

Ikan nilem yang tertangkap, diukur panjang tubuhnya menggunakan papan ukur dengan ketelitian $0,1 \mathrm{~cm}$ dan ditimbang bobot tubuhnya dengan timbangan digital dengan ketelitian 1 gram. Selanjutnya dilakukan pembedahan untuk mengambil sampel isi perut dan gonad, kemudian diawetkan dengan larutan formalin $5 \%$. Pengamatan isi perut dan gonad dilakukan di Laboratorium Biologi Ikan, Balai Penelitian Pemulihan dan Konservasi Sumberdaya Ikan.

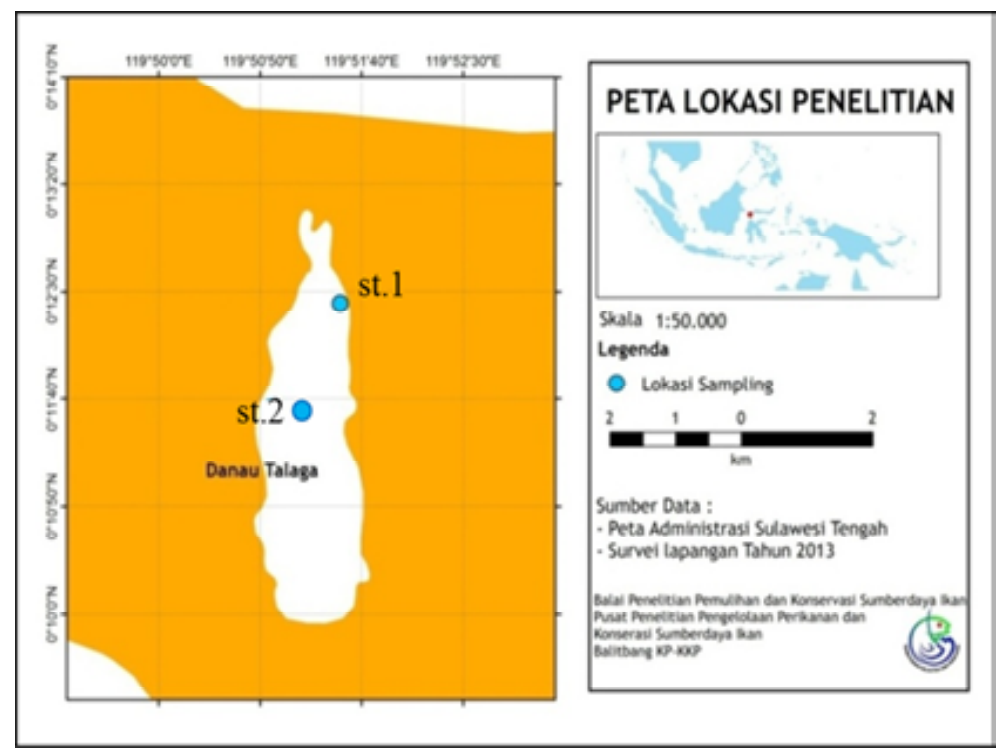

Gambar 1. Peta lokasi penelitian di Danau Talaga Sulawesi Tengah.

Figure 1. Map of research location at Talaga Central Sulawesi Lake.

\section{Analisis data}

Analisis hubungan panjang berat dari ikan nilem menggunakan rumus (Cailiet et al.,1986):

$$
W=a L^{b}
$$

Keterangan :

$$
\begin{array}{ll}
\mathrm{W} & \text { : beratikan }(\mathrm{g}) \\
\mathrm{L} & \text { : panjang ikan }(\mathrm{mm})
\end{array}
$$

$\mathrm{a}$ dan $\mathrm{b}$ : konstanta
Nilai b digunakan untuk menduga pola pertumbuhan yang dianalisis menggunakan hipotesis:

Nilai $b=3$ menunjukkan pola pertumbuhan isometrik Nilai $b_{\neq} 3$ menunjukkan pola pertumbuhan allometrik Jika nilai $\mathrm{b}>3=$ allometrik positif (pertumbuhan bobot lebih cepat)

Jika nilai $\mathrm{b}<3=$ allometrik negatif (pertumbuhan panjang lebih cepat)

Kesimpulan dari nilai b yang diperoleh ditentukan dengan melakukan uji t pada selang kepercayaan 95\% (á $=0,05)($ Steel \&Torrie, 1989). 
Analisis makanan ditentukan dengan menggunakan indeks bagian terbesar (Index of Preponderance) (Natarajan \& Jhingran, 1961):

$I i=\frac{v_{i} \mathrm{o}_{i}}{\sum \mathrm{v}_{i} \mathrm{o}_{i}} X 100$

Keterangan:

$\mathrm{Ii}=$ indek bagian terbesar (Index of Preponderance)

$\mathrm{v}_{\mathrm{i}}=$ persentase volume makanan jenis ke- $\mathrm{i}$

$\mathrm{o}_{\mathrm{i}}=$ presentase frekuensi kejadian makanan jenis ke-i

Tingkat kematangan gonad (TKG) ikan nilem diamati secara visual dengan cara membedah perut ikan dan dilihat tingkat perkembangan gonadnya berdasarkan modifikasi dari Cassie (Tabel 1) (Effendie, 1979).

Ukuran ikan pertama kali matang gonad diketahui dengan menggunakan rumus Spearman Karber (Udupa, 1986):

$\mathrm{m}=\mathrm{x}_{\mathrm{k}}+(\mathrm{X} / 2)-(\mathrm{XSPi})$

Keterangan:

M : log panjang ikan pada kematangan gonad pertama

$\mathrm{x}_{\mathrm{k}}: \log$ nilai tengah kelas panjang dimana semua ikan (100\%) sudah matang gonad

$\mathrm{p}_{\mathrm{i}}$ : proporsi ikan matang pada kelas ke i dimana $\mathrm{pi}=\mathrm{ri} / \mathrm{ni}$ apabila $\mathrm{ni}=\mathrm{ni}+1$

ri : jumlah ikan matang pada kelas panjang ke i

Tabel 1. Tingkat kematangan gonad (TKG) ikan nilem berdasarkan modifikasi dari Cassie (Effendie, 1979) Table 1. Gonadal Stage of bonylip barb based on Cassie modification (Effendie, 1979)

TKG Betina $\quad$ Jantan

I Ovari seperti benang,

panjang, sampai kedepan rongga tubuh. Warna jernih. Permukaan licin

II Ukuran ovari lebih besar. Pewarnaan lebih gelap kekuning-kuningan. Telur belum terlihat jelas dengan mata

III Ovari berwarna kuning. Secara morfologi telur mulai kelihatan dengan mata

IV Ovari makin besar, telur berwarna kuning, mudah dipisahkan. Butir minyak tidak tampak, mengisi 1/22/3 rongga perut, usus terdesak.

V Ovari berkerut, dinding tebal, butir telur sisa terdapat didekat pelepasan. Banyak telur seperti pada tingkat II
Testis seperti benang, lebih pendek (terbatas) dan terlihat ujungnya di rongga tubuh. Warna jernih

Ukuran testis lebih besar. Pewarnaan putih seperti susu. Bentuk lebih jelas daripada tingkat I

Permukaan testis tampak bergerigi. Warna makin putih, testis makin besar. Dalam keadaan diawetkan mudah putus

Seperti pada tingkat III tampak lebih jelas. Testis semakin pejal.

Ovari berkerut, dinding tebal, butir telur sisa terdapat didekat pelepasan. Banyak telur seperti pada tingkat II
Panjang ikan pada waktu mencapai kematangan yang pertama (M) diketahui dengan menggunakan rumus:

$\mathrm{M}=\operatorname{antilog} \mathrm{m}$

Jika $\alpha=0,05$ maka batas-batas kepercayaan $95 \%$ dari (m) adalah:

$\operatorname{Antilog}\left(\mathrm{m} \pm 1,96 \sqrt{ } \mathrm{x}^{2}\left(\mathrm{p}_{\mathrm{i}}{ }^{*} \mathrm{q}_{\mathrm{i}}\right) / \mathrm{ni}-1\right)$

Indeks kematangan gonad (IKG) diketahui dengan cara mengukur bobot gonad dan bobot tubuh ikan termasuk gonad menggunakan timbangan yang mempunyai ketelitian 0,01 gram. Gonad ditimbang dari masing-masing TKG.Nilai IKG ikan nilem TKG IV dianalisis menggunakan rumus Effendie (1979) yaitu:

$$
I K G=\frac{B G}{B T} \times 100 \%
$$

Keterangan:

$\mathrm{BG}=$ Bobot $\operatorname{gonad}(\mathrm{g})$

$\mathrm{BT}=$ Bobot tubuh $(\mathrm{g})$ 
Diameter telur ikan nilem (sub sampel bagian anterior, median dan posterior) diamati dengan menggunakan mikroskop pada perbesaran 10x4, yang telah dilengkapi dengan mikrometer okuler dengan skala 100, dan hasil konversi persatuan skala sebesar $0,025 \mathrm{~mm}$, sedangkan fekunditas dihitung dengan menggunakan rumus :

$F=\frac{G}{Q} x X$

Keterangan:

$\mathrm{F}=$ fekunditas (jumlah telur di dalam gonad)

$\mathrm{G}=$ bobot seluruh gonad $(\mathrm{g})$

$\mathrm{Q}=$ bobot sebagian gonad $(\mathrm{g})$

$\mathrm{X}=$ jumlah telur dari sebagian gonad (butir)

Analisis aspek biologi ikan nilem pada penelitian ini dilakukan dengan menggunakan software Microsoft Excel.

\section{HASIL DAN BAHASAN HASIL}

Ikan nilem (Osteochillus vittatus) yang tertangkap memiliki panjang antara 11-22,7 cm dan berat antara 15,79 - 171,43 g. Ikan nilem merupakan ikan yang paling banyak tertangkap melalui percobaan penangkapan yaitu sebanyak 57- 88\% dari jumlah ikan hasil tangkapan
(Gambar 2). Ikan nilem yang teridentifikasi jenis kelaminnya sebanyak 297 ekor yang terdiri dari 192 ekor ikan betina (64\%) dan 105 ekor ikan jantan (36\%). Selain nilem, jenis ikan lainnya yang tertangkap saat penelitian adalah gabus (Channa striata), nila (Oreochromis niloticus), mujair (O. mossambicus), mas (Cyprinus carpio) dan betok (Anabas testudineus).

\section{Distribusi frekuensi panjang dan hubungan panjang berat ikan nilem}

Sebaran frekuensi kelompok ukuran panjang ikan nilem betina dan jantan hampir ditemukan pada semua kelas panjang (Gambar 3), tetapi ikan nilem jantan pada ukuran $14-15 \mathrm{~cm}$ lebih mendominasi dengan persentase $47 \%$ dari 105 ekor ikan yang ada, sedangkan ikan nilem betina banyak yang tertangkap pada kelompok panjang 13-14 $\mathrm{cm}(21,9 \%)$ dan $14-15 \mathrm{~cm}(27,1 \%)$ dari 192 ekor ikan.

Analisis hubungan panjang berat yang dipisahkan antara ikan nilem jantan, betina dan kombinasi keduanya ditampilkan pada Tabel 2. Nilai b pada ikan nilem kurang dari 3 , setelah dilakukan uji t diketahui $b \neq 3(p<0,05)$, hal ini menunjukkan pola pertumbuhan ikan nilem jantan, betina maupun gabungan keduanya bersifat alometrik negatif, dimana artinya pertumbuhan panjang lebih dominan daripada pertumbuhan bobot.

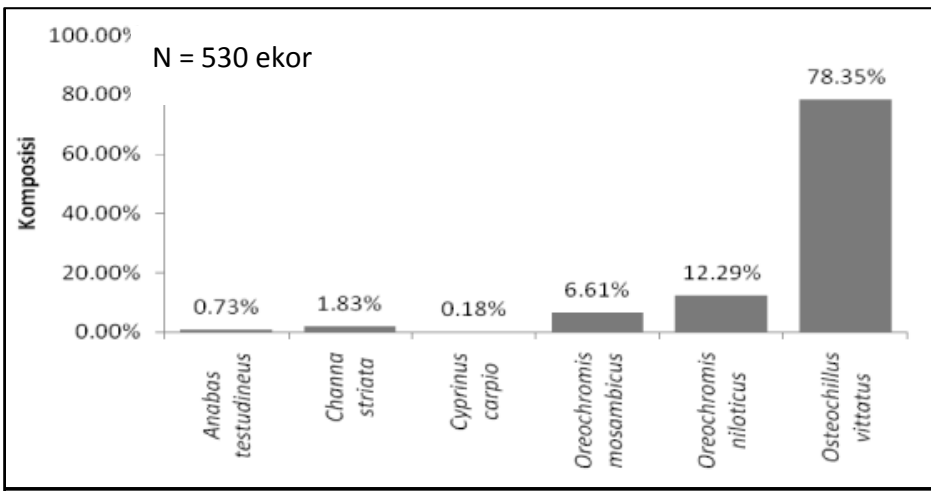

Gambar 2. Komposisi hasil tangkapan ikan di Danau Talaga.

Figure 2. Fish catch composition in Talaga Lake.

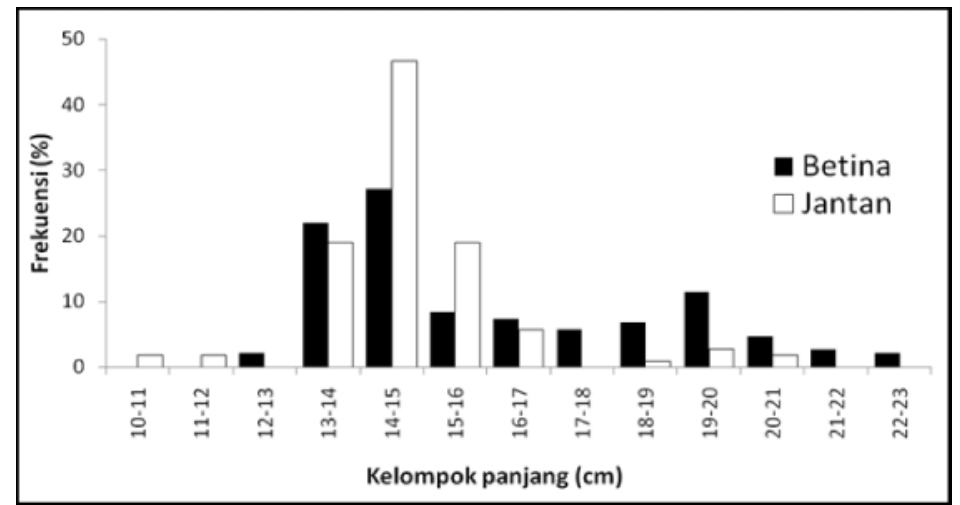

Gambar 3. Distribusi frekuensi panjang ikan nilem jantan dan betina.

Figure 3. Length frequency distribution of Bonylip barb. 
Tabel 2. Hubungan panjang berat ikan nilem di Danau Talaga

Table 2. Length weight relationship of Bonylip barb in Talaga Lake

\begin{tabular}{lccccc}
\hline Jenis Kelamin/Sex & $\mathbf{n}$ & $\mathbf{a}$ & $\mathbf{b}$ & $\mathbf{R}^{\mathbf{2}}$ & $\begin{array}{c}\text { Pola pertumbuhan / } \\
\text { Growth pattern }\end{array}$ \\
\hline Betina(Female) & 192 & 0,016 & 2,888 & 0,93 & Alometrik negatif \\
Jantan (Male) & 105 & 0,036 & 2,590 & 0,817 & Alometrik negatif \\
Gabungan(Combination) & 413 & 0,019 & 2,838 & 0,911 & Alometrik negatif \\
\hline
\end{tabular}

\section{Kebiasaan Makan}

Pengamatan isi perut ikan nilem menunjukkan bahwa tumbuhan merupakan jenis makanan yang paling disukai oleh ikan nilem dengan nilai index of preponderance (Ii) sebesar 96. Beberapa jenis makanan seperti fitoplankton $(2,91)$, zooplankton $(0,004)$, moluska $(0,68)$, serangga $(0,0005)$ dan detritus $(0,21)$ juga ditemukan dalam isi perut ikan nilem. Lampiran 1 menunjukkan komposisi makanan ikan nilem berdasarkan kelompok frekuensi panjang. Ikan nilem mengkonsumsi tumbuhan sebagai makanan utamanya hampir pada semua kelompok ukuran panjang. Hasil ini menunjukkan bahwa ikan nilem merupakan ikan herbivor.

\section{Reproduksi}

Tingkat kematangan gonad (TKG) ikan nilem yang diamati di Danau Talaga didominasi TKG IV, baik jantan atau betina (lebih dari 82\%) (Tabel 3). Kemunculan ikan nilem matang gonad (TKG III dan IV) pada setiap waktu penelitian merupakan indikasi bahwa ikan nilem dapat memijah sepanjang tahun.

Tabel 3. Tingkat kematangan gonad (TKG) ikan nilem Table 3. Gonadal Stage of bonylip barb.
Gambar 4 menunjukkan bahwa ikan nilem betina yang matang gonad (TKG IV) hampir ditemukan pada semua kelompok ukuran panjang. Berdasarkan analisis dengan metode Spearman-Karber, diketahui rata-rata ukuran pertama kali matang gonad (Lm) ikan nilem betina pada panjang 13,8 cm dengan kisaran 13,6-14 cm, sedangkan Lm untuk jantan pada 12,3 cm dengan kisaran $12-12,5$ $\mathrm{cm}$.

Indeks kematangan gonad (IKG) ikan nilem betina pada TKG IV yang diamati dalam penelitian ini berkisar antara $2,5-23,83 \%$ dengan rata-rata $13,05 \pm 4,56 \%$. Sebaran frekuensi diameter telur ikan nilem pada TKG IV ditunjukkan pada Gambar 5. Nilai tengah diameter telur ikan nilem berkisar antara $0,535-1,285 \mathrm{~mm}$, dimana nilai tengah tertinggi berada pada ukuran $0,885 \mathrm{~mm}$ dengan persentase $21,08 \%$.

Fekunditas ikan nilem betina berkisar antara 1.151 47.134 butir, dengan rata-rata $11.370 \pm 8.803$ butir, dimana fekunditas maksimum terdapat pada ikan nilem dengan panjang $21,9 \mathrm{~cm}$ dan berat 149,6 gram.

\begin{tabular}{|c|c|c|c|c|c|c|c|}
\hline \multirow{2}{*}{$\begin{array}{c}\text { Jenis } \\
\text { Kelamin/ } \\
\text { Sex }\end{array}$} & \multirow{2}{*}{$\begin{array}{l}\text { Bulan/ } \\
\text { month }\end{array}$} & \multicolumn{5}{|c|}{$\begin{array}{c}\text { Persentase TKG }(\%) / \\
\text { Percentage of gonadal stage }(\%)\end{array}$} & \multirow{2}{*}{$\begin{array}{l}\text { Total (ekor)/ } \\
\text { Number (ind) }\end{array}$} \\
\hline & & TKG I & TKG II & TKG III & TKG IV & TKG V & \\
\hline \multirow{4}{*}{$\begin{array}{c}\text { Betina } \\
\text { (female) }\end{array}$} & Maret & - & - & 2,15 & 87,10 & 10,75 & 93 \\
\hline & Mei & - & - & - & 100 & - & 42 \\
\hline & Juli & 5,13 & 5,13 & 5,13 & 82,05 & 2,56 & 39 \\
\hline & Oktober & - & - & - & 100 & - & 18 \\
\hline \multirow{4}{*}{$\begin{array}{l}\text { Jantan } \\
\text { (male) }\end{array}$} & Maret & 8,00 & - & - & 92,00 & - & 50 \\
\hline & Mei & - & - & - & 100 & - & 7 \\
\hline & Juli & - & 9,68 & - & 90,32 & - & 31 \\
\hline & Oktober & - & - & - & 100 & - & 6 \\
\hline
\end{tabular}




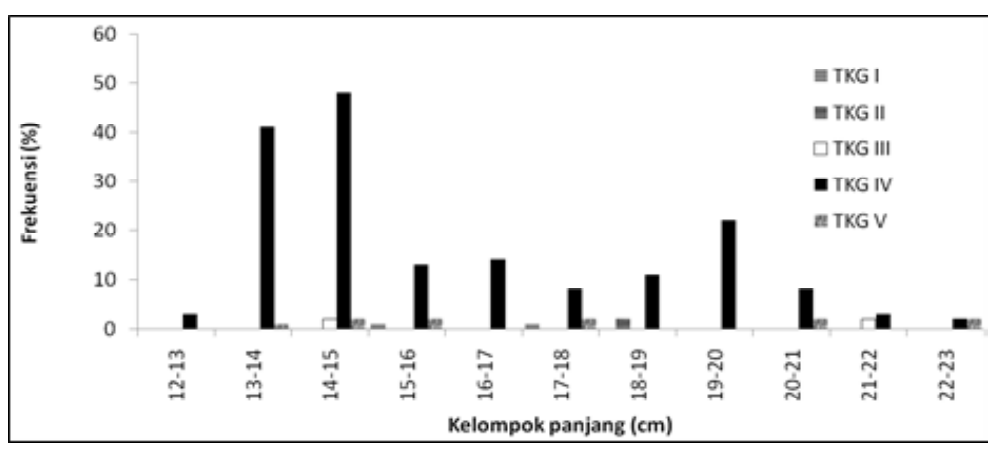

Gambar 4. Tingkat kematangan gonad ikan nilem betina I-V berdasarkan kelompok panjang.

Figure 4. Maturity stage of female Bonylip barb based length groups.

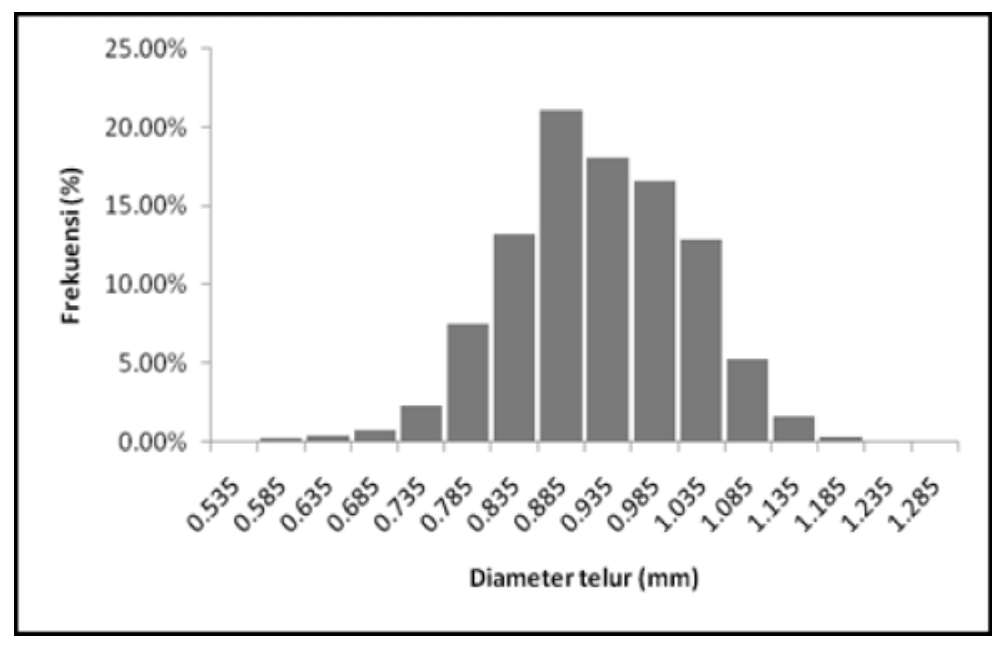

Gambar 5. Sebaran diameter telur ikan nilem TKG IV.

Figure 5. Egg diameter distribution from IV grade maturation of Bonylip barb.

\section{BAHASAN}

Hasil percobaan penangkapan menunjukkan sangat melimpahnya populasi ikan nilem dimana lebih dari $50 \%$ dari total jumlah ikan yang tertangkap selama penelitian berlangsung. Ukuran ikan nilem yang rata-rata tertangkap lebih kecil dibandingkan ukuran ikan nilem yang biasa ditemukan di perairan lain. Ikan nilem (Osteochilus vittatus) yang tertangkap di Waduk Cirata berukuran 16$27,5 \mathrm{~cm}(20,4 \pm 2,5 \mathrm{~cm})$ (Hedianto \& Purnamaningtyas, 2011) dan ikan nilem (Osteochilus vittatus) yang ditemukan di Danau Singkarak berukuran antara 16,2 -28,3 cm (Uslichah \& Syandri, 2003).

Pola pertumbuhan alometrik negatif dari ikan nilem (Osteochilus vittatus) Danau Talaga sama dengan ikan nilem (Osteochilus vittatus) di Danau Poso (Subagja et al., 2013) dan berbeda dengan ikan nilem yang ditemukan di Waduk Cirata dan Danau Singkarak (Hedianto \& Purnamaningtyas, 2011; Uslichah \& Syandri, 2003). Menurut Effendie (1997), berbagai faktor internal dan eksternal dapat mempengaruhi pertumbuhan ikan seperti keturunan, jenis kelamin, umur, parasit, penyakit, jenis makanan dan suhu perairan. Pada daerah tropis, ketersediaan makanan menjadi faktor yang mempengaruhi, dimana tingginya jumlah ikan nilem dalam perairan yang tidak sebanding dengan ketersediaan makanan akan menyebabkan terjadinya kompetisi antar individu.

Analisa isi perut ikan nilem yang menunjukkan bahwa ikan nilem merupakan ikan herbivor sesuai dengan penelitian lainnya(Ekawati et al., 2011; Rainboth, 1996; Hedianto \& Purnamaningtyas, 2011; Subagja et al., 2013). Dugaan sebagian besar masyarakat di sekitar Danau Talaga yang menganggap ikan ini sebagai predator bagi ikan-ikan lain pun tidak terbukti dengan hasil penelitian ini.

Ukuran ikan nilem saat pertama kali matang gonad $\left(\mathrm{L}_{\mathrm{m}}\right)$ lebih kecil dibandingkan $\mathrm{L}_{\mathrm{m}}$ ikan nilem pada beberapa lokasi. Di Danau Singkarak, Lm ikan nilem (Osteochilus vittatus) berkisar antara 18,2-28,3 cm (Uslichah \& Syandri, 2003), begitu juga menurut Luna (2014) dimana $\mathrm{L}_{\mathrm{m}}$ ikan nilem (Osteochilus vittatus) berkisar antara $18-20,23 \mathrm{~cm}$. O'brien (1999) dan Saborido-Rey \& Kjesbu (2012) menyatakan bahwa faktor lingkungan bisa mempengaruhi 
laju kematangan gonad ikan. Menurut Piska \& Naik (2002), laju pertumbuhan ikan sangat tergantung pada faktor lingkungan seperti temperature, oksigen terlarut dan ketersediaan makanan. Penelitian lebih lanjut diperlukan untuk mengkaji pengaruh faktor lingkungan pada kecilnya ukuran ikan nilem yang telah matang gonad di perairan Danau Talaga. Banyaknya ikan nilem berukuran kecil yang telah matang gonad mengindikasikan ikan nilem yang hidup di Danau Talaga memiliki pertumbuhan yang lambat (berumur tua).

Waktu pemijahan ikan dapat diduga dengan melihat proporsi ikan matang gonad yang selalu ditemukan (Bayhan et al., 2005 dan Hedianto \& Purnamaningtyas, 2013). Pada penelitian ini ikan matang gonad padaTKG IV selalu ditemukan pada setiap waktu penelitian yang mengindikasikan ikan nilem dapat memijah sepanjang tahun. Waktu pengambilan sampel ikan nilem yang hanya mewakili empat waktu penelitian, belum bisa menentukan puncak musim pemijahan ikan nilem selama setahun sehingga diperlukan penelitian lebih lanjut, tetapi menurut Hedianto \& Purnamaningtyas (2011)puncak pemijahan ikan nilem (Osteochilus vittatus) di Waduk Cirata terjadi saat musim hujan.

Berdasarkan sebaran nilai tengah diameter telur diketahui bahwa tipe atau pola pemijahan ikan nilem adalah total spawner,yang mengeluarkan telurnya secara serentak pada saat memijah.Tipe pemijahan seperti ini sesuai dengan beberapa penelitian lainnya (Hedianto \& Purnamaningtyas, 2011; Uslichah \& Syandri, 2003).

Fekunditas ikan nilem yang ditemukan di Danau Talaga lebih kecil dibanding perairan lainnya (Uslichah \& Syandri, 2003; Hedianto \& Purnamaningtyas, 2011).Hal ini berhubungan dengan ukuran panjang dan bobot ikan nilem yang ditemukan di Danau Talagajuga lebih kecil dibanding lokasi lainnya.Lampiran 2menampilkan hasil kajian aspek biologi ikan nilem di Danau Talaga, Waduk Cirata dan Danau Singkarak.

Selain karakteristik lingkungan yang cocok dan sifatsifat biologis ikan nilem yang menyebabkan tingginya populasi ikan ini, ikan predator bagi ikan nilem di Danau Talaga tampaknya tidak banyak. Saat dilakukan percobaan penangkapan hanya ditemukan ikan gabus (Channa striata) sebagai ikan predator dan jumlahnya pun tidak banyak (Gambar 2). Tidak seimbangnya populasi nilem dengan populasi ikan predator juga terjadi di Danau Poso (Subagja et al., 2013). Penduduk Danau Talaga sendiri kurang menyukai ikan nilem untuk dikonsumsi, yang menyebabkan peningkatan jumlah nilem di perairanini pun tidak terhindarkan.
Sakai et al. (2001) menyatakan adanya karakteristikkaraketristikyang berdampak pada keberhasilan invasi suatu spesies diantaranyatingginya fekunditas dan laju pertumbuhan, tingkat toleransi terhadap berbagai kondisi lingkungan, penyebaran dan kolonisasi yang cepat, perilaku agresif serta daya saing. Suatu jenis ikan akan disebut IAS (invasive alien species) jika ikan asing yang diintroduksi (sengaja atau tidak) menyebabkan dampak negatif bagi lingkungan (turunnya keanekaragaman ikan asli, perubahan atau kerusakan habitat, polusi, dan lainlain) serta meningkatnya masalah ekonomi dan sosial (European Commission, 2014; Anonim, 2009). Banyaknya ikan nilem yang tertangkap mungkin belum bisa mengindikasikan bahwa ikan nilem adalah ikan invasive karena ikan ini sebenarnya masih bisa dimanfaatkan. Walaupun minat masyarakat sekitar Danau Talaga untuk mengkonsumsi ikan nilem masih rendah tetapi ikan ini bisa diolah dan dipasarkan ke daerah lain.Beberapa daerah penghasil nilem khususnya di Pulau Jawa mengolah ikan ini menjadi baby fish goreng, dendeng, pindang, nilem asap dan nilem kaleng (Rahardjo \& Marliani, 2007dalam Wijayanti, 2013), telurnya pun berpeluang menjadi komoditas eksporsebagai kaviar(sejenis makanan dari telur ikan)(Soeminto, 2010 dalam Wijayanti, 2013) dan benihnya jika dilatih bisa menjadi ikan untuk terapi (Sudarmo, 2011 dalamAnonim, 2009).

\section{KESIMPULAN}

Ikan nilem merupakan ikan yang dominan tertangkap di Danau Talaga dengan kisaran panjang antara 11-22,7 $\mathrm{cm}$ dan berat antara 15,79-171,43 g, dimana ikan dengan panjang antara $14-15 \mathrm{~cm}$ mendominasi tangkapan (37\%).Ikan nilem dikategorikan sebagaiikan herbivor dengan makanan utamanya adalah tumbuhan (93\%).Ikan nilem yang dominan tertangkap berada pada TKG IV, dimana ukuran pertama kali matang gonad $\left(\mathrm{L}_{\mathrm{m}}\right)$ baik jantan atau betina lebih kecil dibandingkan $\mathrm{L}_{\mathrm{m}}$ ikan nilem pada beberapa referensi. Hal ini mengindikasikan bahwa ikan nilem di Danau Talaga matang gonad pada ukuran yang lebih kecil karena memiliki pertumbuhan yang lambat (berumur tua). Tipe pemijahan ikan nilem di Danau Talaga adalah total spawner dan dapat memijah sepanjang tahun. Dominasi ikan nilem pada percobaan penangkapan menunjukkan tingginya populasi ikan nilem di Danau Talaga, dan diduga akan terus meningkat jika tidak segera dimanfaatkan. Dibutuhkan perhatian dari para pemangku kepentingan terkait di sekitar Danau Talaga, khususnya pemerintah daerah Kabupaten Donggala, agar ikan ini bisa diolah sehingga bermanfaat secara ekonomis. Pemanfaatan ikan nilem juga akan memberikan manfaat secara ekologis karena akan mengurangi resiko terjadinya ledakan populasi ikan nilem di Danau Talaga. 


\section{DAFTAR PUSTAKA}

Anonim. 2009. What are Invasive Alien Species. Diaksesdari https://www.cbd.int/idb/2009/about/what/ 10 April 2014.

Cailiet, G.M., M.S. Love \& A.W. Ebeling. 1986. Fishes: A Field and Laboratory Manual on Their Structure, Identification and Natural History. Waveland Press, Inc. Long Grove, Illinois: 194 pp.

Dinas Kelautan dan Perikanan Sulawesi Tengah. 2012. Pengkayaan sumberdaya ikan di Danau Telaga dan Danau Lindu. Diunduh dari http://www.dkp.sulteng.go.id/v2/index. php?option $=$ com_content $\&$ view $=$ article $\&$ id $=94$ : pengkayaan-sumberdaya-ikan-di-danau-Telaga-dand anau-lindu \& catid $=28$ : bidang-perikanantangkap\&Itemid=66 12Februari 2014 .

Effendie, M.I. 1979. Metoda Biologi Perikanan. Penerbit Yayasan Dewi Sri. Cetakan I, Bogor. 112 hlm.

Effendie, M.I. 1997. Biologi Perikanan. Penerbit Yayasan Pustaka Nusatama. Bogor. 157 hlm.

Ekawati, D., S. Astuty \& Y. Dhahiyat.2011. Studi kebiasaan makan ikan nilem (Osteochilus hasselti $\mathrm{CV}$ ) yang dipelihara pada keramba jaring apung di Waduk Ir.H.Djuanda Jawa Barat. Jurnal Akuatika 2 (1): 12 hal.

European Commission. 2014. Developing an EU Framework for Invasive Alien Species. Discussion Paper. Diunduh dari http://ec.europa.eu/environment/nature/ invasivealien/docs/ias_discussion_paper.pdf 10 April 2014.

Hedianto, D.A \& S.E. Purnamaningtyas. 2011. Beberapa aspek biologi ikan nilem (Osteochilus vittatus, Valenciennes, 1842). Prosiding Seminar Nasional Perikanan Indonesia 2011: 95-107.

Hedianto, D.A \& S.E. Purnamaningtyas. 2013. Biologi reproduksi ikan golsom (Hemichromis elongatus, Guichenot 1861) di Waduk Cirata, Jawa Barat. Bawal widya riset perikanan tangkap 5 (3) : 159-166.

Kottelat, M., 1998. Fishes of the Nam Theun and Xe Bangfai basins, Laos, with diagnoses of twenty-two new species (Teleostei: Cyprinidae, Balitoridae, Cobitidae, Coiidae and Odontobutidae). Ichthyol. Explor. Freshwat. 9 (1):1-128. Diunduh dari http:// www.fishbase.org/Summary/speciesSummary.php?I
$\mathrm{D}=277 \&$ genusname $=$ Osteochilus $\&$ speciesname $=$ vittatus\& AT=osteochilus+vittatus \&lang=Bahasa. Tanggal 26 Februari 2014.

Natarajan, A.V \& A. C. Jhingran. 1961. 'Index of preponderance'-a method of grading the food elements in the stomach analysis of fishes. Indian $J$. Fish 8: 54-59.

O'brien, L. 1999. Factors influencing the rate of sexual maturity and the effect on spawning stock for georges bank and gulf of maine atlantic cod Gadus morhua stocks. J. Northw. Atl. Fish. Sci. 25: 179-203.

Piska, R.S \& S.J.K. Naik. 2002. Fish Biology and Ecology (Fisheries). 349 p.

Rainboth, W.J. 1996. Fishes of the Cambodian Mekong. FAO Species Identification Field Guide for Fishery Purposes. FAO, Rome. 265 p. Diunduh dari http:// fishbase.us/summary/Osteochilus-vittatus.html 14 Februari 2014

Saborido-Rey, F \&O.S. Kjesbu. 2012. Growth and maturation dynamics. Diunduh dari http:// digital.csic.es/bitstream/10261/47150/3/ $\mathrm{Grow}$ th $\% 20$ and $\% 20 \mathrm{matur}$ at i on $\% 20$ dynamics\%20\%281\%29.pdf 30 Juli 2015.

Sakai, A.K., F.W. Allendorf,J.S. Holt, D.M. Lodge, J. Molofsky, K.A. With, S. Baughman, R.J. Cabin,J. E. Cohen, N. C. Ellstrand, D. E. McCauley, P. O’Neil, I. M. Parker, J. N. Thompson \& S. G. Weller. 2001. The population biology of invasive species. Annu. Rev. Ecol. Syst.32: 305-332.

Steel, R. G. H. \& J. H. Torrie. 1989. Prinsip dan prosedur statistika: suatu pendekatan biometrik (diterjemahkan oleh Bambang Sumantri). Edisi kedua. PT. Gramedia. Jakarta. 748 p.

Subagja, J., R. Gustiano \& L. Winarlin. 2007. Pelestarian ikan nilem (Osteochilus vittatus C.V) melalui teknologi pembenihannya. Prosiding Lokakarya Nasional Pengelolaan dan Perlindungan Sumber Daya Genetik di Indonesia: Manfaat Ekonomi untuk Mewujudkan Ketahanan Nasional: 279-286.

Subagja, S. Sawestri, D. Atminarso \& S. Makmur. 2013. Aspek biologis dan penangkapan ikan nilem (Osteochillus vittatus, VALENCIENNES 1842) di perairan Danau Poso Sulawesi Tengah. Prosiding Pertemuan Ilmiah Tahunan Masyarakat Liminologi Indonesia: 20-32. 
Udupa, K.S. 1986. Statistical method of estimating the size at first maturity in fishes. Fishbyte 4 (2): 8-10. ICLARM. Metro Manila.

Uslichah, U \& H. Syandri. 2003. Aspek reproduksi ikan sasau (Hampala sp.) dan ikan lelan (Osteochilus vittatusc.v.) di Danau Singkarak. Jurnal Iktiologi Indonesia 3 (1): 41 -48.

Wijayanti, G.E. 2013. Panduan teknis pembenihan ikan nilem secara intensif. Diunduh dari http:// bio.unsoed.ac.id/sites/default/files/ Panduan\%20Teknis\%20Pembenihan\%20Ikan\%20 Nilem\%20secara\%20Intensif-.pdf 10 April 2014.

Zhu, F.-Y., S.-W. Ye, Z.-J. Li, T.-L. Zhang, J. Yuan, Z.-Q. Guo, J.-F. Tang\&J.-S. Liu. 2014. Growth and reproduction of the non-native iceûsh Neosalanx taihuensis Chen, 1956 (Salangidae) in a plateau lake, southwestern China.Appl. Ichthyol. 30: 862-869. 
Lampiran 1. Index of preponderance ikan nilem berdasarkan kelas panjang $(\mathrm{cm})$ Appendixl. Bonylip barb Index of preponderance based length class ( $\mathrm{cm}$ )

\begin{tabular}{cccccccc}
\hline $\begin{array}{c}\text { Kelas ukuran } \\
\text { Panjang (cm) } \\
\begin{array}{c}\text { Length size class } \\
\text { (cm) }\end{array}\end{array}$ & n & $\begin{array}{c}\text { Fitoplankton } \\
\text { Phytoplankton }\end{array}$ & $\begin{array}{c}\text { Zooplankton } \\
\text { Zooplankton }\end{array}$ & $\begin{array}{c}\text { Tumbuhan } \\
\text { Plant }\end{array}$ & $\begin{array}{c}\text { Moluska } \\
\text { Mollusk }\end{array}$ & $\begin{array}{c}\text { Detritus } \\
\text { Detritus }\end{array}$ & $\begin{array}{c}\text { Serangga } \\
\text { Insects }\end{array}$ \\
\hline $10-11$ & 1 & 10,00 & & 90,00 & & & \\
$11-12$ & 1 & 70,00 & & 30,00 & & & \\
$12-13$ & 2 & & & 100 & & & \\
$13-14$ & 33 & 1,47 & - & 97,12 & 1,21 & 0,20 & - \\
$14-15$ & 55 & 3,35 & 0,00 & 95,60 & 0,56 & 0,49 & - \\
$15-16$ & 21 & 6,29 & 0,03 & 91,51 & 1,55 & 0,59 & 0,03 \\
$16-17$ & 11 & 12,08 & 0,10 & 87,82 & - & - & - \\
$17-18$ & 6 & & & 100,00 & & & - \\
$18-19$ & 9 & - & - & 99,21 & 0,79 & - & - \\
$19-20$ & 13 & 4,81 & 0,02 & 95,18 & - & - & - \\
$20-21$ & 6 & - & - & 87,30 & 12,70 & - & - \\
$21-22$ & 2 & 0,27 & - & 98,73 & - & 1,00 & - \\
$22-23$ & 2 & & & 100,00 & & & \\
\hline
\end{tabular}

